\title{
Mecanismul ereditar și căutarea factorilor necunoscuți ai evoluției ${ }^{\dagger}$
}

\author{
Henry Fairfield Osborn
}

„Infirmați principiul lui Lamarck și vom fi obligați să presupunem că, în cadrul evoluției, există un al treilea factor despre care nu știm nimic"1. În rîndul factorilor necunoscuți ai evoluției se află relațiile care subzistă între diferitele stadii ale dezvoltării și mediu.

Analiza recentei discuții dintre Spencer și Weismann din „Contemporary Review” duce la concluzia că nici unul dintre acești doi recunoscuți lideri în științta biologiei nu își întemeiază poziția pe dovezi inductive. Fiecare își risipește forțele în critica distructivă a celuilalt; nici unul nu-şi prezintă punctul de vedere în mod constructiv, în aşa fel încît să impună convingere fie oponentului său, fie altora. Pe scurt, sub stratul de polemică fină, vedem cum acești lideri susțin ca definitiv fixate teorii care se întemeiază mai puțin pe fapte și mai mult pe improbabilitățile logice ale teoriilor rivale. $\mathrm{O}$ astfel de concluzie este profund semnificativă; în concepția mea, ea marchează un punct de cotitură în istoria speculației, căci este sigur că nu ne vom opri cercetarea la fiecare factor al evoluției întemeiat mai degrabă pe logică decît pe demonstraţia inductivă. Dacă vom face astfel și vom accepta ca stabilite legi care se sprijină în mare măsură pe raționamentul negativ, în istoria științei se va deschide un capitol retrograd.

Rezultatul cel mai puțin sesizabil al acestei discuții prelungite, dar cu adevărat cel mai important și mai persistent este sentimentul crescînd al nevoii de inducție și de dovezi inductive. Iniţiatorul real al noii mișcări este Weismann, deși aceasta a luat o direcție pe care el nici nu a prevăzut-o, nici nu a susținut-o, poziția sa fiind eminamente conservatoare. În fapt, primul său serviciu permanent adus Biologiei este cererea de dovezi directe ale principiului lamarckian, care a dus la cererea din sens opus a unor astfel de dovezi ale propriului său principiu, al selecției-cerere pe care, prin ceea ce vădește și încă mai mult prin ceea ce spune în discuția cu Spencer, nu este în stare să o împlinească. Al doilea serviciu permanent al său-după cum îi amintește E.B. Wilson autoruluieste că a adus în prim plan relația dintre mecanismul ereditar și evoluție.

Ce am cîștigat de pe urma controversei ultimului deceniu, în afară de gîndirea aprofundată și de această acută recunoaștere a nevoii de mai multă observație? Poate că ne rămîn unele ipoteze de lucru, noi și folositoare, cu privire la posibilele căi ale evoluției, și o deplină înțelegere a uriașei dificultăți a chestiunii eredităţii-dar acestea sînt doar cîștiguri indirecte. Un cîștig direct este că aceste rezultate negative au condus o mînă de biologi la o reacție totală față de speculație și către o stare general-agnostică în relație cu teoriile moderne, reacție și stare care sînt de departe mai sănătoase și mai de ajutor decît spiritul încrezător al majorității, fie în neo-lamarckism, fie în neo-darwinism. Nu există semn de progres în afirmația dogmatică conform căreia chestiunea este stabilită fie după Spencer, fie după Weismann, decît dacă această afirmație poate fi susținută de dovezi; dar cine poate prezenta dovada, dacă nu stăpînii chestiunii? Cînd cernem făina de pleavă, cînd aducem laoaltă din toate sursele fenomene de diferite tipuri şi căutăm să discernem care sînt capacitățile exacte ale acestor fenomene, ajungem cu toții la convingerea că încă ne aflăm în pragul chestiunii evoluției și că secretul este în cea mai mare parte legat de cel al fenomenelor vitale, în general.

${ }^{\dagger}$ Din Prelegerile de biologie de la Marine Biological Laboratories, Woods Holl. Această prelegere provine, în principal, dintr-un articol publicat de către autor în Merkel und Bonnet: Ergebnisse fur Anatomie und Entwicklungsgeschichte, Freiburg, 1894, și parțial dintr-un articol citit înaintea Biological Section of the British Association for the Advancement of Science: Certain Principles of Progressively Adaptive Variation observed in Fossil Series, „Nature”, aug., 30, 1894. Textul de față este traducerea în limba română a formei apărute în „The American Naturalist”, vol. 29, nr. 341, mai, 1895, p. 418-439, CrossRef.

${ }^{1}$ H. F. Osborn, Sînt transmisibile variațiile dobîndite?, în „Diacronia”, 1, 13 ian., 2015, art. A16, p. 13, CrossRef. 
Diferențele dominante de opinie, foarte ample și concrete, se pot atribui în cea mai mare măsură nefirescului divorț dintre diferitele ramuri ale biologiei, extremei noastre specializări moderne, lipsei noastre de eclectism în biologie. Abia atunci cînd datele de teren și din laborator sînt așezate cap la cap cu datele paleontologiei, laolaltă cu cele ale antropologiei, împreună cu faptele de variație umană și legile eredității umane, începem să sesizăm magnitudinea problemei, deoarece, în embriologia modernă, cu siguranță că descoperirea cea mai strălucită este că baza fizică a întregii eredități este aceeaşi, de aici decurgînd probabilitatea ridicată ca legile eredităţii să fie aceleaşi pentru întreaga lume organică, fără granițe între protozoare şi metazoare, sau între animale și plante. Atît Weismann cît și Spencer se arată orbi la această conexiune a unității fundamentale, atunci cînd trasează anumite linii de separație în ereditate, în vreme ce nici una dintre acestea nu există în mecanismul ereditar cunoscut al cromatinei și al arheoplasmei. Avînd aceste descoperiri în minte, nu apare Weismann la fel de rătăcit atunci cînd susține că moștenirea trăsăturilor dobîndite este un principiu aflat în declin în evoluția vieții, la fel cum apare Spencer cînd susține că, în evoluția vieții, acesta este un principiu în creștere?

Prin urmare, primul pas către progres este recunoaşterea directă a limitelor cunoașterii noastre și a eșecului nostru actual de a întemeia pe inducție fie lamarckismul, fie neo-darwinismul, ca principii universale. Al doilea este recunoașterea faptului că întreaga noastră gîndire încă se concentrează în jurul a cinci ipoteze de lucru, pînă acum propuse, și anume cele ale lui Buffon, Lamarck, Saint-Hilaire, Darwin și Nägeli. De cînd au fost ei concepuți, critica modernă a diferențiat cît se poate de mult acești factori, dar nu i-a transformat în mod esențial. Putem doar privi la „supraviețuirea celui mai adaptat”, a lui Darwin, ca la un factor real, demonstrat dincolo de orice dubiu, fără a ne angaja noi înşine în „originea adaptării”" Cel de-al treilea pas este de a recunoaște că ar putea exista unul sau mai mulți factori necunoscuți, care ar putea produce o surpriză le fel de mare precum cei ai lui Darwin. Sentimentul că lucrurile stau astfel i-a venit pentru prima dată autorului în 1890, reflectînd asupra nevoii unei explicații pentru caracterul defi- nit și aparent intenționat al anumitor variații ${ }^{2}$. De atunci, un sentiment similar a fost exprimat de către Romanes și alții, și mai apoi de către $S \operatorname{cott}{ }^{3}$, dar cea mai puternică expresie a acestuia vine recent dinspre Driesch $^{4}$, în inferența sa că există un factor nu doar necunoscut, ci și de necunoscut!

Teoretic, nici una dintre aceste cinci ipoteze ale zilei nu o exclude pe cealaltă. Ele pot coopera. Rolul pe care îl joacă fiecare, sau destinul fiecăruia în istoria speculației depinde în mare măsură sau pe de-a întregul de soluția la problema transmiterii sau netransmiterii trăsăturilor dobîndite şi, în cele din urmă, ceea ce s-a scris despre această chestiune trebuie privit de către fiecare observator imparțial ca fiind încă nerezolvat.

Sîntem departe de a face testele finale sau de a înlătura acești factori vechi, dar răspunsul obținut din speculația asupra acestora este în sine o acceptare tacită a faptului că trebuie să căutăm un ce încă necunoscut. Dacă există așa ceva, atunci sînt slabe șanse de a-l descoperi fără cea mai laboriaosă cercetare; și, în timp ce nu ne împiedică nimic să prezicem că dovada decisivă a existenței sale va fi găsită în morfologie, este bine să adăugăm că fericitul descoperitor va fi un fiziolog.

\section{Analiza Variației.}

După aceste observații introductive, să examinăm un alt rezultat al controversei, anume că variaţia și ramura de cercetare înrudită, evoluția experimentală, se află acum în prim plan ca cele mai importante și mai aducătoare de speranță dintre toate modalitățile în care se pot transforma testele inductive ale factorilor cunoscuți și necunoscuți. Fie-ne îngăduit să facem o onorabilă exceptare a acelor reacționiști, precum Bateson $^{5}$ și Weldon, care au transformat o cercetare precisă în legi ale variației.

Cum ar trebui continuat studiul variației? Mă deosebesc complet de punctul de plecare al lui Bateson, în ceea ce privește perspectiva adoptată în introducerea la lucrarea sa, că cea mai bună metodă de a începe o astfel de cercetare stă în renunțarea la analiza care se sprijină deopotrivă pe experiență și pe baza mai mult sau mai puțin speculativă a cercetării trecute. Se cîștigă puțină înțelegere clară dacă se

\footnotetext{
${ }^{2}$ Op. cit., 1891.

${ }^{3}$ În Variations and Mutations, „American Journal of Science”, noe., 1894.

${ }^{4}$ Analytische Theorie der Organischen Entwicklung, Leipzig, 1894.

${ }^{5}$ W. Bateson, Materials for the Study of Variation, Londra, 1894.
} 
consideră variaţiile en masse, iar în această prezentare voi înfățişa cîteva motive pentru care lucrurile stau astfel în acest caz, precum şi unele principii care par a precede unei adunări și clasificări inteligente de fapte, încredințat fiind că o simplă înșiruire de fapte nu ar duce la nimic. Variația trebuie privită ca una dintre cele două modalități sau expresii ale eredității sau ca exponentul vechilor forțe ale ereditățiii, dezvoltînduse în condiții noi şi instabile. Ea nu se află în contrast cu ereditatea, care o include, ci cu repetiția, ca exponent al vechilor forțe care se dezvoltă în condiții vechi sau stabile. Acum zece ani, Nägeli ${ }^{6}$ a reliefat acest lucru, așa cum au făcut mai tîrziu Weismann, Bateson, Hurst ${ }^{7}$ și alții. Cu toate acestea, ea este, în mare parte, greșit concepută. Hurst chiar privește variația ca cel mai vechi fenomen-o eroare aflată la cealaltă extremă, deoarece ele sînt mai degrabă fenomene coincidente-reprezentînd caracterul stabil sau instabil al dezvoltării. Cea mai largă analiză pe care o putem face este că variațiile se separă în trei planuri-al timpului, al cauzei și al adecvării. Acest lucru solicită rezolvarea a trei probleme, cu referire la fiecare variație: cînd a apărut variația?, ce a cauzat-o?, este sau nu adaptativă?

În legătură cu aceste trei planuri de analiză, cercetărorul eredității are, aşadar, a examina tipurile de ereditate ca fiind complementare sau interacționale, deoarce imediat ce o „variație” revine în mai multe generații, practic ea este o „repetiţie”, iar principiul repetiției este o sursă frecventă a variației sau îndepărtării, aparente dar nu reale, a urmaşului din tipul sau specia parentală. Această relație devine limpede atunci cînd analizăm variațiile la om, aşa cum apar în Anatomie și în studiile lui Galton asupra moștenirii, și aşa cum sînt ele prezentate în tabelul următor:

\section{EREDitate.}

Repetiție.

$A$. Tip retrograd către prezent și trecut.

(a) repetarea tipului parental.

(b) regresul către tipul de specie prezent, de regulă la nivelul mai multor trăsături (= variație de la tipul parental actual).

(c) întoarcerea la tipul trecut de specie, de regulă la nivelul uneia sau mai multor tră săt u ri (= variație de la tipul actual de specie).

Variație paligenică.
Variație.

$A$. Neutră atît în ceea ce privește prezentul cît şi viitorul. Incluzînd anomalii și aberații care sînt fenomene pur individuale, nu căi ale evoluţiei.
$B$. Progresivă către tipul viitor.

(a) v a r i a ți e ontogenică de la tipul parental, la nivelul uneia sau al mai multor trăsături.

(b) variație ontogenică de la specia actuală, la nivelul mai multor trăsături (= un sub-tip nou).

(c) variaţie filogenică sau constantă către tipul viitor de specie, la nivelul uneia sau al mai multor trăsături, constituind o nouă „varietate" (= repetarea tipului parental).

Cel mai mare decalaj în timp se află între „variațiile paligenice", provenind din istoria trecută a individului, și „variațiile cenogenice”, care au a face numai cu istoria prezentă și viitoare. Prima dintre acestea cuprinde mai mult decît revenirea. Acest tabel ne oferă prima impresie a planului temporal, atît de superficial privit de către Bateson—dacă, într-adevăr, este posibilă discriminarea între datele de tipul celor pe care le-a cules. Substanța distinctivă a anatomiei

\begin{abstract}
Variație cenogenică.
umane $^{8}$ este că o comparație între trecutul și prezentul habitudinilor unei specii sau al uzurilor la care sînt și au fost puse oasele și mușchii deschide calea unei posibile analize a variațiilor, atît în ceea ce privește vremea apariției lor, cît și adecvarea lor la uzurile lor trecute, prezente și viitoare, prin urmare fiind o sursă inepuizabilă pentru studiul filozofic al variației-din
\end{abstract}

\footnotetext{
${ }^{6}$ „Vererbung und Veränderung sind, wenn sie nach dem wahren Wesen des Organismen bestimmt werden, nur scheinbare Gegensätze”, Theorie der Abstammungslehre, p. 541.

${ }^{7}$ Biological Theories. I, The Nature of Heredity, „Natural Science”, vol. I, nr. 8, 8 oct., 1892.

${ }^{8} \mathrm{R}$. Wiedersheim, Bau des Menschen als Zeugniss seiner Vergangenheit, Freiburg, 1887.
} 
care doar nivelele superioare au fost exploatate 9 . În afara organismului uman nu există un altul la îndemîna noastră, care să permită o atît de exactă analiză a variației, în planurile temporal și al adecvării. Iarăși, atunci cînd racordăm anatomia umană ca domeniu de studiu al variației, cu cercetările lui Galton-în ciuda faptului că el a pus accentul, în principal pe legile repetiției-începem să apreciem marea importanță a inducțiilor sale. Spre deosebire de cele ale lui Weismann, acestea se întemeiază pe fapte și vor rămîne în picioare. În primul volum al acestor prelegeri de la Marine Biological Laboratory am ajuns să arăt pînă la un anumit nivel de detaliu felul în care prezintă Galton problema evoluției moderne, astfel încît aici pot doar să recapitulez pe scurt. El demonstrează două principii: primul, că în organisme trebuie să existe o puternică tendință progresivă variațională, pentru a compensa puternicul principiu retrograd al repetiției, oriunde prevalează efectul neutralizator sau de împotmolire al încrucișării naturale, așa cum se întîmplă, în mod virtual, cu cele mai multe trăsături anatomice ale rasei umane. În cel de-al doilea, el arată ceea ce, sub acest aspect, nu a fost subliniat înainte, că în cadrul încrucişării naturale variațiile ontogenice sau individuale sînt evidente, dar mai ales temporare, în vreme ce există un curent subteran al variațiilor filogenice, relativ greu de remarcat și permanente. $\mathrm{O}$ altă dovadă care sprijină acest ultim principiu decurge din cele ce urmează.

Care este valoarea distincției dintre variațiile ontogenice și filogenice? Aceasta: ea pune bazele discutării foarte neglijatei chestiuni inițiale a vremii apariției unei variații în istoricul vieții unui individ. Acesta este primul pas în experimentarea variației, nu doar întrucît va permite obținerea de dovezi hotărîtoare cu privire la factorii lui Buffon, Lamarck și ai lui Saint-Hilaire-care țin de moștenirea trăsăturilor dobîndite-, dar și avînd în vedere viitorul cercetărilor acurate asupra variației în general. Să considerăm că variaţia ontogenică-o sintagmă mai întîi folosită de către Brooks, cred, cu toate că nu pot arăta unde-se referă la toate devierile de la tip, care își au cauza în oricare etapă a dezvoltării individuale.
Începem acum să recunoaștem pe deplin că cauzele anumitor tipuri de variație pot fi de fapt urmărite retrospectiv către influențele externe ale anumitor stadii de creștere sau ontogenie, și că, în cele din urmă—atunci cînd chestiunea timpului se lămurește pe cale experimentală—, va fi posibil să se determine aceste stadii. Să considerăm că variația fllogenicăo sintagmă mai întîi folosită de către Nägeli ${ }^{10}$ cuprinde acele abateri de la tip care au devenit trăsături ereditare constante în anumite serii filetice sau chiar în cîteva generații. De vreme ce toate variațiile filogenice trebuie să-și aibă originea în ontogenie sau într-un anumit stadiu al dezvoltării individuale, cu siguranță că o proporție foarte mică din nenumăratele variații ontogenice, pe care le găsim la examinarea sau măsurarea oricărui individ adult, devin filogenice sau constituie mai mult decît unde pe suprafața valului.

Această distincție fundamentală nu a fost avută în vedere pînă acum. Statisticile variației, așa cum au fost întocmite de către Darwin și mai apoi de către Wallace, Weldon, Bateson și alții, nu iau în calcul faptul că printre variaţiile filogenice există altele pur ontogenice, care apar și dispar pe parcursul vieții individului, datorîndu-se cauzelor legate doar de perturbarea acțiunii tipice a mecanismelor ereditare, pe parcursul ontogeniei. Cu alte cuvinte, acești autori șiau întemeiat, în mod nediscriminatoriu, pe variaţiicare pot fi în mare măsură sau pe de-a întregul ontogenice şi temporare-importantele principii ale „variației fortuite”, a lui Darwin, și „,variaţiei discontinui”, a lui Bateson, în timp ce doar legile variaţiei filogenice constituie adevăratul sprijin al chestiunii evoluției. Să luăm drept ilustrare a acestei metode false măsurătorile aripilor la păsări făcute de către Wallace. De ce nu pot fi acestea în mare măsură cazuri de variație ontogenică pură, datorată influențelor habitudinilor vieții sau vreunei perturbări pur temporare a temeliei eredităţii ? Înainte de orice, neodarwiniștii trebuie să reconsidere principiul „variaţiilor fortuite", care constituie o inducție a datelor variațiilor ontogenice și filogenice amestecate, deoarece neo-darwinismul este o teorie esențialmente și exclusiv a supraviețuirii variațiilor filogenice favorabile.

\footnotetext{
${ }^{9}$ H.F. Osborn, Present Problems in Evolution and Heredity. The Cartwright Lectures. I. The Contemporary Evolution of Man etc. Wm. Wood \& Co. New York, 1891.

${ }^{10}$ „Die Veränderung, die gewönlich der Vererbung gegenüber gestelt wird, steht nicht in Gegensatz zu dieser, sondern zur Constanz. In diesem Sinne heisst eine Veränderung constant, wenn das Gewonnene dauernd behalten, und vergänglich, wenn es bald wieder preisgegeben wird. Die constante oder die phylogenetische Veränderung... ist eigentlich nichts anderes als die Conctitutionsänderung des Idioplasmas", Theorie der Abstammungslehre, p. 277.
} 
Prin urmare, unul dintre aspectele problemei actuale ar putea fi formulat astfel: Care este cauza, natura și proporţia variaţiilor ontogenice în diferite stadii de dezvoltare, și în ce condiții devin filogenice variațiile ontogenice?

Aceasta ne aduce la o analiză a variațiilor ontogenice în plan temporal, după cum se vede deocamdată în tabelul următor:

\section{Originea VARIAȚiIlor DE-A LUngul Istoricului Vieţi \\ A. Variații Ontogenice. \\ Teorii ale Cauzelor.}

(a) Gonagenice, adică apărînd în celulele germinale, incluzînd „variațiile blastogenice”, din perspectiva lui Weismann, „variațiile primare”, din cea a lui Emery.

(b) Gamogenice, adică apărînd în timpul maturării și fertilizării, incluzînd „variațile blastogenice”, din perspectiva lui Weismann, sau „variațiile weismanniene", din cea a lui Emery.

(c) Embriogenice, adică de la primele diviziuni celulare, incluzînd „variațile blastogenice” şi „somatogenice”, din perspectiva lui Weismann.

(d) Somatogenice, adică apărînd în timpul dezvoltării larvare și apoi, după formarea celulelor germinale.
Teoretic legate de influențe patologice, chimico-fizice nutritive, nervoase, aşa cum le concepe von Kölliker şi alții, incluzînd fenomenele îndoielnice de xenie și telegonie.

Teoretic legate de influențele deja numite, de asemenea cu combinarea diferitelor trăsături ancestrale, „amfimixia” lui Weismann.

Teoretic legate de anomalii extensive datorate segmentării anormale și altor cauze, așa cum se observă în embriologia mecanică a lui Roux, Driesch, Wilson și a altora.

Legate de reacțiile dintre forțele ereditare de dezvoltare ale individului și ale mediului.

\section{B. Variații Filogenice.}

Variații de la tip, avîndu-și originea în oricare dintre stadiile de mai sus, și care devin ereditare.

Tabelul de mai sus ilustrează limitele care desigur că nu ar trebui să fie prea fin trasate între stadiile succesive ale ontogeniei, în ciuda faptului că trebuie să existe puncte focale intermediare cu adevărat distincte. Cei patru termeni propuși nu trebuie luați în sensul 'blastogenic' și 'somatogenic' al lui Weismann, deoarece aici nu se petrece o petitio principi, și anume de separare a substanței ereditare sau a plasmei germinale de celulele somatice. Chiar înainte ca separarea somatogenică să aibă loc avem puține motive sau chiar deloc să credem că toate variațiile blastogenice, gonagenice sau gamogenice, care este posibil să fi apărut din diferite cauze, să devină filogenice.

Dacă mergem cu analiza în "planul adecvării", primul element care apare este dacă variațiile sînt normale, inclusiv cele cenogenice și cele paligenice, sau anormale, inclusiv malformațiile teratologice și de altă natură. Termenii fortuit și nedefinit, spre deosebire de determinat și definit, pot fi folosiți separat de oricare teorie, cu toate că ei au apărut spre a distinge două perspective diferite cu privire la principiile variaţiei. Caracterul fortuit implică în mod riguros variația în preajma unei medii potrivite, în vreme ce definit nu este echivalentul necesar al variației adaptative, ci pur și simplu implică variația progresivă sau filogenică într-o direcție pe care Waagen și Scott au numit-o mutație. Termenii lui Bateson, continuu și discontinuu sînt folositori întrucît disting variația graduală de cea ontogenică.

În general, cele cinci ipteze de lucru, privitoare la factorii evoluției, se referă teoretic la stadiile temporale ale variației, după cum se vede în tabelul următor:

$$
\operatorname{Buffon}\left\{\begin{array}{ll}
\text { Ontogenică } \\
a & \text { gonagenică } \\
b & \text { gamogenică } \\
c & \text { embriogenică } \\
d & \text { somatogenică } \\
& \text { Filogenică }
\end{array}\right\} \text { Saint-Hilaire }
$$


Atrag atenția asupra faptului că neo-darwinismul a presupus pînă acum și practic a acceptat ca bază a sa variația fortuită filogenică, întrucît se leagă exclusiv de selecția acelor variații ontogenice care sînt totodată filogenice. Pe de altă parte, neo-lamarckismul relaționează exclusiv cu variațiile somatogenice, care se moștenesc. Factorul lui Buffon, al acțiunii directe a mediului, se află în centrul tuturor celor patru etape ontogenice și, atît teoretic cît și după cum se observă pe cale experimentală, produce profunde variații ontogenice; întrebarea este: în ce circumstanțe se produc astfel de variații ontogenice, în fiecare dintre cele patru etape devenite filogenice? Acest factor ar putea fi înlăturat—parțial, nu total—de dovada că variațiile somatogenice nu sînt moștenite. Factorul lui SaintHilaire, al acțiunii mediului asupra stadiilor timpurii de dezvoltare, ar genera variaţii pur fortuite și, după cum el însuşi a observat cu limpezime, ar fi necesară selecția pentru a-i imprima o direcție adaptativă. Pe de altă parte, factorul lui Nägeli presupune variația definită, dar nu în mod necesar fllogenic adaptativăopiniile sale în această chestiune au fost cît se poate de greșit înțelese-și, după cum a arătat, factorul său ar necesita, totodată, selecție, spre a determina care dintre direcțiile definite ale creșterii sînt adaptative.

Se pare, așadar, că este necesar să se indice cu limpezime relațiile dintre stadiile temporale ale variației și cei cinci factori, spre a arăta punctele decisive de sprijin pe care le va avea viitorul cercetării noastre. De exemplu, dovada că variația este fie definită fie adaptativă, anterioară sau independentă de selecție, va infirma definitiv, nu teoria lui Darwin, ci neodarwinismul. Pe de altă parte, soarta lamarckismului depinde de demonstrarea faptului că variația filogenică nu este doar definită și adaptativă, ci și că este anticipată prin faptul de a corespunde cu variația somatogenică.

O analiză a ideilor recente asupra chestiunii variației arată că aceste etape ale vieții ajung să fie general recunoscute. Voi trece peste factorii lui Lamarck și Darwin-atît de bine înțeleși-și voi vorbi doar despre ceilalți trei.

\section{FaCtorul VARIAȚiei, AL LUi BUfFon}

În ceea ce privește factorul lui Buffon, care este cel mai cuprinzător dintre toți, știm că Spencer și Weismann deopotrivă au presupus că acțiunea directă a mediului a fost la început un factor al evoluției. Weismann a fost primul care l-a privit ca pe unica sursă a variației protozoarelor, dar recent i-a acordat un rol mai mare în acțiunea mediului asupra celulelor germinale, ca o cauză nu a variației definite, ci a variabilităţii. Direcția de cercetare a acțiunii directe a mediului în privința influenței lui asupra variației somatogenice, urmată de către Hyatt, Dall și alții, are o paralelă în speculațiile mai recente care conectează direct mediul de stadiile gonagenic şi gamogenic, inițiate de către Virchow ${ }^{11}$, von Kölliker ${ }^{12}, Z_{\text {iegler }}{ }^{13}$, Sutton și alții. În același filon se află sugestile lui Geddes, în vreme ce acelea ale lui Gerlach și Ryder își îndreaptă atenția în principal către alterările mecanice din stadiile de dezvoltare embrionară. Botaniști precum Vines, Detmer și Hoffmann au subliniat influența mediului asupra variaţiei gonagenice. Experiențe cu caracter general conducînd în principal la variații embriogenice și somatogenice au fost făcute recent de către Cunningham, Agassiz și alții, ilustrînd acțiunea directă a mediului. Totodată, adepții factorului lui Buffon sînt considerați, mai mult sau mai puțin, lamarckiști. Distincția este cu deosebire exprimată în termenii kinetogenic și statogenic, ai lui Cope și Ryder, deoarece sub influența factorului lui Buffon organismul este pasiv, în vreme ce sub cea a factorului lui Lamarck este activ. Printre cei care au sprijinit principiul lui Buffon se află Packard, Eimer, Cunningham, Ryder și Dall.

Această literatură și aşa-numita dovadă referitoare la factorul lui Buffon vădesc cea mai mare confuzie posibilă în interpretare și demonstrează că concepțiile noastre, în primul rînd cu privire la ereditate, apoi cu privire la variația în condiţiile schimbării mediului, necesită o minuțioasă restructurare ${ }^{14}$. În primul rînd în ceea ce privește evoluția în relație cu ereditatea. Fenomenele de reversibilitate observate în

\footnotetext{
${ }^{11}$ R. Virchow, Descendenz und Pathologie, „Virchow Archiv”, CIII, p. 1866, p. 1-15; 205-215; 413-437. Über den Transformismus, „Archiv fur Anthropologie”, 1889, p. I.

${ }^{12}$ A. von Kölliker, Das Karyoplasma und die Vererbung, „Zeitschrift fur wissenschaftliche Zoologie”, 1886, Eröfnung der ersten Versammlung der Anatomischen Gesellschaft in Leipzig, „Anatomischer Anzeiger”, II, 1887.

${ }^{13}$ E. Ziegler, Die neuesten Arbeiten über Vererbung und Abstammungslebre und ibre Bedeutung für die Pathologie, Tübingen.

${ }^{14}$ J.T. Cunningham, The Problem of Variation, „Natural Science”, vol. III, p. 282-287. De asemenea, Research on the Coloration of the Skins of Flat-Fishes, „Journal of the Marine Biology Association, mai, 1893 (a se vedea și „Philosophical Transactions of the Royal Society of London", 1892-1893.).
} 
anatomia umană înlătură pe de-a întregul concepția asupra evoluției, a lui Weismann, ca selecție favorabilă și eliminare a variațiilor ereditare nefavorabile; cu alte cuvinte, a selecției acționînd asupra plasmei germinale. Aceste fenomene indică mai degrabă că procesul direct nu este unul de eliminare, ci de suprimare din ultimele stadii ale ontogeniei, și că numai după un interval uriaș de timp apare eliminarea efectivă. Condiții nervoase anormale, precum cele constatate în cazul anencefaliei, sînt însoțite de resuscitarea unui număr mare de trăsături latente. În limbajul lui Galton, în cursul evoluției, trăsăturile manifeste devin latente.

Pe de altă parte, în limbajul lui Weismann, în explicarea dimorfismului la himenoptere și la alte tipuri există anumite seturi de biofori corespunzînd anumitor posibilități ale dezvoltării adultului. Aplicați acestea la cunoscutul caz al pleuronectiformelor și la remarcabilele rezultate recent obținute de către Agassiz, Filhol și Giard, în producerea artificială a peștilor plați, mai mult sau mai puțin simetrici, prin reținerea puietului aproape de suprafață. Interpretarea lui Weismann asupra evoluției peștilor plați a fost mereu că acest lucru s-a produs prin selecția determinantelor asimetrice și eliminarea celor simetrice. În lumina acestor experimente, el trebuie acum să-și remodeleze explicația spunînd că peștii plați au ținut în rezervă un set de determinante simetrice, din vremea în care apare prima noastră înregistrare a tipului asimetric, adică de acum trei milioane de ani!

Acest atac asupra speculațiilor unui autor este o digresiune. În fapt, ceea ce vreau să scot la iveală este necesitatea unei analize mult mai critice a diferitelor tipuri de dovezi în favoarea factorului lui Buffon. Această necesitate poate fi ilustrată de diferitele interpretări ale schimbării culorii ca răspuns direct la schimbarea mediului.

Cele mai semnificative experimente referitoare la culoare sint cele ale lui Cunningham asupra pleuronectiformelor. El a demonstrat că în timpul metamorfozei timpurii a peștilor plați tineri, cînd pigmentul încă este prezent pe ambele părți, acțiunea luminii reflectate nu previne dispariţia pigmentului de pe partea care se află în jos, astfel încît culoarea trece rapid printr-o dezvoltare retrogradă. Expunerea prelungită la lumină, însă, a părții de jos face ca pigmentul să reapară, și, imediat după apariția sa, petele de pigment sînt similare sub toate aspectele cu cele prezente în mod firesc pe partea superioară a peștelui. Este foarte important să nu se confunde aceste rezultate, care sînt de mare interes, cu cele obținute atunci cînd mediul este nou în istoricul experienței organismului. Prin urmare, experimentele asupra culorii permit o ilustrare pregnantă a necesității de a trasa o distincție fină între variațiile cenogenice și paligenice. În multe cazuri întîlnim repetări greșite ale tipurile structurale vechi în locul structurilor nou achiziționate. Cînd palidul Proteus este luat din peșterile Australiei, pus la soare, iar în decursul unei luni capătă pigmenți întunecaţi, fie am resuscitat o trăsătură latentă, fie am creat o trăsătură nouă. Cea din urmă interpretare poate fi luată drept probă în favoarea factorului lui Buffon doar dacă se află că este urmată de transmiterea ereditară.

Poulton ${ }^{15}$, ca un susținător al neo-darwinismului, adoptă această opinie, în replică la Beddard și Bateson, și ca o inducție de la aceste minunate și acurate experimente asupra colorației larvelor de lepidoptere. După ce produce cele mai variate colorații și marcaje, înconjurînd larvele pe perioada ontogeniei cu obiecte de diferite culori, el susține că schimbările directe produc pur și simplu revenirea la adaptări la condiții anterioare de viață, cu alte cuvinte că ele sînt paligenice. Fie că acesată interpretare este corectă sau nu, Poulton dovedește că, indiferent de cît de stabile par a fi anumite trăsături ereditare, repetarea în ontogenie depinde de repetarea în mediu, și că variația ontogenică se petrece între limite largi, ea neputînd deveni filogenică, cel puțin pentru cîteva generații succesive.

Din multe alte cercetări analoage deducem principiul căruia i s-a acordat prea puțină atenție, în cadrul studierii fenomenelor de variație, sprijinite pe factorii evoluției: repetiția ontogenică depinde in mare măsură de repetiția în mediu și în habitudinile vieții, in vreme ce variația ontogenică este legată de variația in mediu și in habitudinile de viață. Dacă mediul se schimbă înspre unul vechi, atunci variaţiile ontogenice tind către regres sau revers (adică paligenie) sau, practic, către repetarea unui tip vechi. Este necesar să se arate cu limpezime că există dovezi practic hotărîtoare pentru un astfel de principiu, nu doar în

\footnotetext{
${ }^{15}$ E. B. Poulton, Further experiments upon the color-relation between certain lepidopterous larva, pupe, cocoons, and imagines and their surroundings, „Philosophical Transactions of the Entomological Society of London”, pt. IV, p. 293, 1892 (conține o replică către Beddard și Bateson.).
} 
ultimele stadii de dezvoltare, precum în metamorfozele respiratorii ale amfibienilor, dar mergînd înapoi pînă la stadii mai timpurii decît ne-am imaginat pînă acum. Prin urmare, în realitate, o cantitate mare de mărturii scoase la iveală spre a demonstra factorul lui Buffon, adică al acțiunii directe a mediului în producerea variațiilor definite și adaptative ontogenic, de cele mai multe ori nu demonstrează nimic.

Eliminînd, aşadar, erorile de interpretare, va rămîne marea întrebare referitoare la ce se întîmplă atunci cînd mediul este pe deplin nou în experiența istorică a organismului. Manifestă variaţiile ontogenice o nouă direcție? Este adaptativă această direcție, adică se îndreaptă către adaptarea progresivă? Ce relații prezintă astfel de condiții cu posibilităţile ereditare ale celulelor germinale?

Dincolo de actualele cercetări devine clar că de acum înainte experimentarea poate fi direcționată distinct asupra celor patru etape de dezvoltare, și că, într-o anumită măsură, va fi posibil în felul acesta să se schițeze astfel de linii de separație. Noile influențe mecanice și chimice pot fi aplicate în fiecare etapă și decupate în etape subsecvente, dificultatea constînd în a atinge punctul extrem în care se exercită o profundă influență, fără a interfera cu funcția de reproducere.

Un efect al noului mediu asupra etapelor gonagenică, gamogenică şi embriogenică va fi variația saltatorie. Ryder $^{16}$ a tratat recent acest lucru într-o modalitate foarte sugestivă, în cadrul discuției originii carasului auriu japonez. Întorcîndu-ne la ipoteza lui Saint-Hilaire, avem în minte variația saltatorie embriogenică, care poate fi urmărită mai cu seamă prin schimbările respiratorii și chimice. Virchow extinde cauza schimbării bruște înapoi la influențele chimico-fizice asupra celulelor germinale. Cauzele și tipurile dezvoltării bruște care apar în oricare etapă ontogenică necesită cea mai atentă investigare, în principal în ceea ce privește întemeierea lor pe relația variației onotgenice cu cea filogenică. Galton a discutat subiectul în mod obiectiv, sub titlul Stabilitatea salturilor, iar Emery, sub titlul Variații primare, a sprijinit observația lui Galton, că astfel de salturi arată adesea o puternică capacitate în direcția moștenirii. În concluzia lucrării sale, Bateson ajunge la o formă modificată a factorului evoluției prin salturi, al lui Saint-Hilaire, și crede că speciile își au originea în mare măsură în discontinuitatea variației sau în sporirea bruscă a noilor trăsături, din cauze necunoscute, concluzionînd că întreaga investigație a cauzelor variaţiei este prematură. Materialele pe care le-a strîns laolaltă sînt de cea mai mare valoare și a reuşit deja să coboare îndoiala la nivelul multor credințe răspîndite, precum că variabilitatea este mai mare la animalele domestice decît la cele sălbatice. După cum am văzut, interpretrea sa asupra acestor materiale slăbește, atît cît se sprijină pe cercetarea actuală a factorilor evoluției, prin faptul că, dată fiind natura celor mai multe dovezi ale sale, el nu poate distinge între variațiile ontogenică și filogenică; mai mult, el respinge orice încercare de a distinge între variația paligenică și cea cenogenică. Această carență a analizei îl conduce la ceea ce pare a fi o inducție pe dea întregul eronată, deoarece principiul discontinuității se opune prin dovezi puternice variaţiei filogenice continui și definite, aşa cum se observă la actualele serii filetice.

\section{FACTORUL LUI NägELI ȘI VARIAȚIA FILOGENICĂ.}

Factorul lui Nägeli ${ }^{17}$ ne introduce într-un teritoriu cu totul aparte-în extrema opusă saltului brusc. Este unul pe care nu-1 mai putem îndepărta ca transcendental pe baza puternicei asemănări pe care o prezintă la prima vedere cu principiul perfecționării interne al lui Aristotel. El este sprijinit cu circumspecție de către van Kölliker și Ziegler. Conține marele element de adevăr că șuvoiul variațieişi prin urmare cel al evoluției-este predestinat prin constituția organismului, adică, date fiind o anumită constituție ereditară şi un mediu favorabil dezvoltării ei, această dezvoltare va manifesta anumite direcții definite, care atunci cînd ating o valoare de supraviețuire vor fi acționate prin selecție. Recent am descris $^{18}$ ca potențial de variație similară un principiu al evoluției care pare a fi bine sprijint de dovezi paleontologice. Acesta este: în vreme ce mediul și activitatea organismului pot alimenta stimulii într-o modalitate necunoscută nouă, din anumite cauze ancestrale foarte îndepărtate se ivesc tendințe definite de

\footnotetext{
${ }^{16}$ The inheritance of modification due to disturbance of the early stages of development, especially in the Japanese domesticated races of gold-carp, „Proceedings of the Academy of Natural Sciences of Philadelphia”, 1893, p. 75.

${ }^{17}$ C. W. von Nägeli, Mecanisch-physiologische Theorie der Abstammungslehre, München și Leipzig, 1884.

${ }^{18}$ Rise of the Mammalia in North America, „Contr. Biol. Dept. Columbia College”, vol. I, nr. 2, sept., 1893.
} 
variație. De pildă, în miocenul mediu, molarii calului și ai rinocerului începeau să prezinte variații similare; cînd acestea sînt urmărite retrospectiv, pînă în etapa embrionică și chiar în cele ancestrale ale dezvoltării dinților dintr-o perioadă geologică timpurie, se descoperă că șase vîrfuri din coroana eocenului, repetate pînă astăzi în dezvoltarea embrionică a fălcii, de asemenea erau centrii variației filogenice; acești centri par a fi predeterminat pînă în ce puncte vor apărea anumite structuri, după ce aceste două linii ale ungulatelor s-au separat printr-un imens inteval de timp. $\mathrm{Cu}$ alte cuvinte, variația din miocenul tîrziu a fost condiționată de structura tipului ancestral din miocenul timpuriu.

Acesta este locul potrivit pentru a aminti o concepție înrudită asupra variației, care se află în mintea multora și a cărei formulare clară apare la Waagen. Aceasta este că variaţie e atît de greu de observat şi de slabă încît poate fi recunoscută ca atare doar atunci cînd sînt așezați alături doi indivizi separați pe durata unei lungi serii de generații ${ }^{19}$. Este de reținut contrastul cu evoluția saltatorie extremă a lui SaintHilaire sau, iarăși, cu concepția asupra variațiilor, a lui Darwin și Weismann, ce-i drept, lipsite de caracter brusc, dar îndeajuns de importante şi de evidente încît să devină factori în cadrul supraviețuirii organismului. După cum am văzut, această concepție a variaţiei filogenice este concordantă cu aplicarea principiilor lui Galton la evoluția umană, însă cel mai puternic sprijin și-l află în paleontologie, și reprezintă motivul inconștient pentru care-pe cît le cunosc opiniile-toți paleontologii, lucrînd independent în diverse colțuri ale lumii, se ridică împotriva teoriei variației fortuite și a selecției.

Seriile noastre paleontologice sînt unice prin caracterul lor filetic. Ele nu prezintă dovezi de fortuitate în ceea ce privește principalele direcții de evoluție. Noile structuri apar prin începuturi infinitezimale, în puncte definite. În stadiile lor prime, ele nu au valoare utilă sau de supraviețiire. Ele cresc în mărime în generații succesive pînă cînd ating stadiul utilității. În multe cazuri ele se ridică mai întîi în puncte care s-au aflat în uz maxim, astfel părînd a sprijini teoriea kinetogenezei. În seriile extensive de fosile de asemenea găsim dovezi ale variațiilor anomalice sau neutre, așa cum a adunat Bateson, dar acestea se află în afara direcției principale a evoluției. Ele nu oferă nici o dovadă în sprijinul principiului neo-darwinist al acumulării adaptative a variațiilor, în afara jocului fortuit în jurul unei medii a trăsăturilor adaptative sau neadaptative, dar oferă o puternică dovadă în favoarea principiului darwinian al supraviețuirii celui mai puternic. Principala tendință a evoluției este directă și definită pretutindeni, conform anumitor legi necunoscute, iar nu conform întîmplării. Acest principiu al adaptării progresive poate fi privit ca stabilit inductiv prin studii minuțioase ale evoluției dinţilor şi scheletului. În 1889, am arătat felul în care acesta influențează factorul transmiterii variației somatogenice, al lui Lamarck; el nu dovedește în mod absolut factorul lui Lamarck deoarece lasă deschisă posibila acțiune a unui alt factor, necunoscut în prezent, factorul lui Lamarck fiind totodată inadecvat; dar el stabilește în mod categoric caracterul universal al factorului lui Darwin, sub aspectul originii adaptărilor și, în consecință, autosuficiența selecţiei naturale. Dacă, pe alte căi, factorul lui Lamarck este respins, ca ipoteză de lucru, deocamdată ne lasă in vacuo.

Concluziile pe care Hyatt, Dall, Williams, Buckman, Lang și Würtemberger le-au obținut de la nevertebrate sînt în mod independent dublate de cele ale lui Cope, Ryder, Baur, $\mathrm{Scott}^{20}$, autorul și mulți alți morfologiști. Aceeași interpretare general filozofică a evoluției este anunțată acum în mod independent, dinspre un domeniu de activitate complet diferit, de către Driesch. Putem abandona aplicațiile acestor fapte în favoarea teoriilor, dar să nu întoarcem spatele înseși faptelor!

\section{Perspectivele Inducției.}

Problemele pe care le-am prezentat aici sînt fundamentale. Nemaifiind induşi în eroare de variaţia paligenică, datorată reînvierii unui mediu vechi, să ne ocupăm cu rigoare de analiza și investigarea răspunsurilor organismului la noul mediu, în toate cele patru stadii de dezvoltare. Sînt acesta răspunsuri adaptative? Există un mecanism teleologic în materia vie, aşa cum a susținut Pflüger ${ }^{21}$ ? Se reflectă acest

\footnotetext{
${ }^{19}$ Acest lucru a fost arătat de către autor în articolul său de la Oxford. A se vedea „Nature”, 30 aug., 1894, p. 435. Recent a fost arătat în mod independent și cu mare limpezime de către Scott, în articolul său Variations and Mutations, „American Journal of Science”, noe., 1894. Pe urmele lui Waagen, Scott reia termenul mutație penru care Nägeli folosea sintagma variație filogenică.

${ }^{20}$ W. B. Scott, On Some of the Factors in the Evolution of the Mammalia, „Journal of Morphology”, vol. V, 1891, p. 378.

${ }^{21}$ E. Pflüger, Die teleologischen Mechanik der lebenden Natur, Bonn, 1877.
} 
mecanism în adult și este acumulat în sămînță?

Perspectiva cea mai optimistă se află în evoluționismul experimental. Acum trei secole, în Nova Atlantis, Bacon a proiectat un institut pentru astfel de experimente, care atunci cînd va deveni realitate ar trebui să se numească Institutul Baconian. Mai tîrziu, dl. Romanes a propus să se întemeieze un astfel de centru în Oxford, și a ajuns atît de departe încît a instituit o importantă serie de experimente private care, din nefericire, au fost întrerupte de moartea sa. Ceea ce vrem să stabilim este dacă noile variații ontogenice devin filogenice, şi cît timp le ia acest lucru.

Condițiile unui experiment hotărîtor pot fi stabilite după cum urmează: un organism, A, avînd un mediu sau deprinderi $A$, este transferat în mediul sau deprinderile $\mathrm{B}$, iar după una sau mai multe generații prezintă variațiile $\mathrm{B}$; apoi, acest organism este transferat în mediul sau deprinderile A, iar dacă prezintă în continuare, fie și pentru o singură generație sau tranzitoriu, oricare dintre variațiile $B$, experimentul constituie o demonstrare a moștenirii variațiilor ontogenice. Virtual, acestea sînt condițiile pe drept cerute de către neo-darwiniști, pentru o demonstraţie categorică a principiului lui Lamarck și al lui Buffon, al moștenirii variației embriogenice sau somatogenice, dar este important să se observe că, în natură, o astfel de revenire la un mediu anterior este foarte rară. Nu s-a înregistrat îndeplinirea pînă acum a unor astfel de condiții, deoarece pînă acum organismele au fost pur și simplu reținute în mediul nou, iar profundele modificări manifestate pot fi pur şi simplu reprezentantele unui mecanism ereditar acționînd sub influența noilor forțe. Probabil că astfel de experimente solicită o perioadă întinsă de timp, întrucît paleontologia ne arată, în aceeași măsură precum variația paligenică, că, în natură, moștenirea filogenică este extrem de lentă.

Este de dorit să se stabilească experimente necontagioase, implicînd condiții dinainte menționate, în principal ca test pentru factorul lui Lamarck. Varigny a mai propus o serie de experimente cruciale, în principal asupra factorului lui Buffon. Volumul său asupra Experimental Evolution este o analiză neprețuită, mai ales a cercetărilor franceze în transformismul experimental. Multe dintre acestea sînt pe direcția stabilită acum cîțiva ani de către Semper, în Animal
Life. Varigny schițează o distincție concludentă între variația morfologică și cea fiziologică, incluzînd în aceasta din urmă diferențele chimice și constitutive care nu apar la nivelul structurii, dar trebuie să se afle la baza tuturor reacțiilor. Sub titlul a ceea ce am numit variație gonadică, autorul discută lucrul lui Gautier ${ }^{22}$ asupra influenței fertilizării prealabile a plantelor, precum și asupra chimiei plantelor, în legătură cu variația coloristică. La observațiile lui Yung şi Born el adaugă alte studii asupra determinării sexului. El descrie teratogenia experimentală sau variația embrionică la Dareste, Fallon și la ultimii observatori.

De-a lungul volumlui lui Varigny este cît se poate de evident că, pînă acum, nici unul dintre studiile asupra variației ontogenice nu a fost anume orientat către problema vitală, așa cum ar trebui să fie de acum înainte. Varigny face o sugestie utilă cu referire la importanța imitării condițiilor naturale, în cadrul activităţii experimentale, dar nu reuşește să sublinieze importanţa setului de teste edificat spre a determina dacă modificările dobîndite au fost realmente imprimate dinspre mecanismul ereditar sau pur și simplu dinspre diferitele stadii ale ontogeniei.

\section{ConcluziI.}

Concluzia generală la care ajungem în urma examinării întregului domeniu este că, în ceea ce privește factorii lui Buffon şi Lamarck, nu avem o teorie a eredităţii, în vreme ce noul factor darwinian sau neo-darwinismul prezintă o explicație inadecvată a evoluției. Dacă variațiile dobîndite se transmit, în ereditate, prin urmare, trebuie să existe un principiu necunoscut; dacă ele nu se transmit, trebuie să existe un factor necunoscut în evoluţie.

În ceea ce privește selecția, avem mai mult decît obiecțiile teoretice avansate de către Spencer și alții. Neo-darwinismul se centrează, ca pe niște principii universale, pe variația întîmplătoare, utilitate și selecție. Seriile fosile complete dovedesc că aceste trei principii, deși importante, nu sînt universale. Anumite structuri adaptative noi apar gradual, conform anumitor legi definite, dar nu și întîmplătoare.

În momentul de față, factorii lui Lamarck și Buffon permit doar o explicație parțială a acestor variații filogenice definite, chiar dacă se acceptă transmiterea trăsăturilor dobîndite. Factorul lui Nägeli, al anumi-

${ }^{22} \mathrm{~A}$. Gautier, Du Mécanisme de la Variation des Êtres vivants. (Hommage à Monsieur Chevreul à l'occasion de son Centenaire), F. Alcan, Paris, 1896. 
tor direcții inerente ale variaţiei se verifică în măsură însemnată în seriile de fosile, ca un principiu al variației determinate, dar nu ca o tendință internă către perfecțiune. Factorul lui Saint-Hilaire, al evoluției saltatorii ocazionale prin modificări bruște ale mecanismului ereditar, este întemeiat, dar încă neînțeles, cu toate că ne apropiem, poate, de o explicație, pe calea embriologiei experimentale.

Poziția noastră față de variație, în relație cu toți factorii, solicită o temeinică reconsiderare. Legea darwiniană a întîmplării și legea lui Buffon, a acțiunii directe a mediului, au fost pînă acum inducții din variații, care pot fi în mare parte ontogenice și tranzitorii. Ambele cer confirmarea dinspre datele variației filogenice. În ceea ce privește factorul lui Lamarck, pare a fi hotărîtoare dovada că variația somatogenică este în mare măsură adaptativă, dar rămîne de demonstrat că variațiile filogenice, așa cum se observă la nivelul anatomiei umane și în paleontologie, sînt invariabil anticipate de schimbările de la nivelul individului, cu alte cuvinte că fluxul definit al variației este condus de moștenirea reacțiilor individului, iar nu de vreun alt principiu.

O altă cocnluzie este că variaţia individuală poate juca un rol mult mai puțin evident decît i-am atribuit, cu alte cuvinte că multe dintre cele mai importante schimbări în rîndul generaţiilor succesive sînt atît de graduale încît sînt pe de-a întregul neobservate la nivelul unei generații.

Concepția noastră asupra mecanismului sau a temeiului fizic al eredităţii de asemenea va deveni mai clară în urma unor experimente direcționate către variația paligenică, spre a determina măsura în care reușește revenirea vechiului mediu să provoace forțele ereditare latente. Experimentele deja destul de avansate ale lui Cunningham, Agassiz și Poulton arată că moștenirea progresivă este mai degrabă un proces de substituție a anumitor trăsături și capacități decît eliminarea efectivă presupusă de către Weismann.

Închei prin a spune că pășim peste pragul chestiunii evoluției în loc să stăm dinaintea intrării. Cea mai grea sarcină se află înaintea noastră, nu în spatele nostru, iar soluția ei ne va purta cu adevărat în secolul al douăzecilea.

[Traducere de Adina Chirilă și Francisc Gafton] 